\title{
Institutions and entrepreneurship: Empirical evidence for OECD countries
}

\author{
Latif Khalilov, Chae-Deug Yi
}

\section{A B S T R A C T}

Objective: The objective of the article is to test the bidirectional association of institutions and entrepreneurship in 19 OECD countries over the period of 2014-2016.

Research Design \& Methods: Most of the previous studies emphasise the role of institutions in entrepreneurial activity, while ignoring the role of entrepreneurship in the building of institutions. We estimate how institutions and entrepreneurship relate to each other and contribute to economic growth. For the estimation, we apply the structural equation modelling (SEM) with panel data.

Findings: Estimated results show that the regulatory dimension of institutions and entrepreneurship have a strong bidirectional relationship - as we expected - while the normative dimension of institutions and entrepreneurship have a unidirectional association. These two interrelated factors stimulate economic growth.

Implications \& Recommendations: Policymakers should create a more friendly regulatory environment for entrepreneurship to flourish. In this process, institutional entrepreneurs also play an important role.

Contribution \& Value Added: There is a need for research on the bilateral relationship between institutions and entrepreneurship. Most previous articles consider the effect that is transmitted from institutions to entrepreneurship. However, there exists a two-way causal relationship between institutions and entrepreneurship that is worth exploring. In this regard, the greatest contribution of this article is that it is one of the first empirical works devoted to testing the two-way causal relationship between institutions and entrepreneurship.

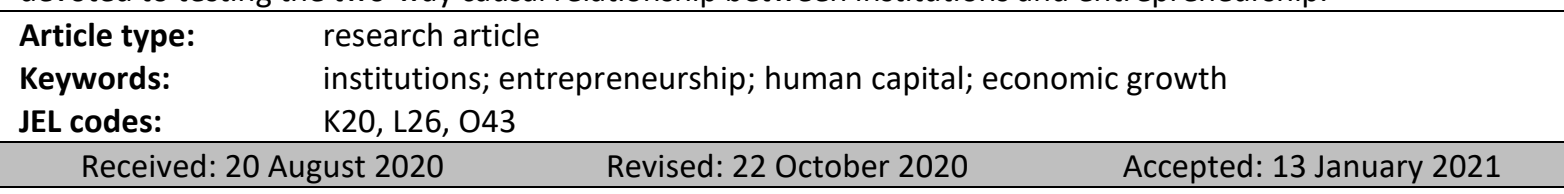

\section{Suggested citation:}

Khalilov, L., \& Yi, Ch.D. (2021). Institutions and entrepreneurship: Empirical evidence for OECD countries. Entrepreneurial Business and Economics Review, 9(2), 119-134. https://doi.org/10.15678/EBER.2021.090208

\section{INTRODUCTION}

The study of the new institutional theory dates back to the 1970s (Scott, 2008) and has spawned a big audience of scientists who continue to contribute to its development. Since the theory's beginnings, numerous articles have been presented to explain the part of institutions in society. North (1990) offers the following definition of institutions: "[i]nstitutions are the rules of the game in a society or, more formally, are the humanly devised constraints that shape human interaction." Simply put, institutions are the rules and norms that we, as people, follow in our daily lives (Sautet, 2005). However, the study of the institutional theory has paid very little attention to entrepreneurship, and the association between these two interrelated components of economic development remains implicit (Sine \& David, 2010).

This fact raises two interrelated questions on the relationship between institutions and entrepreneurship (Sine \& David, 2010; Tolbert, Davide, \& Sine, 2011):

RQ1: How do institutions influence entrepreneurial activity?

RQ2: How does entrepreneurship impact the existing institutional environment? 
We should note that the impact of institutional quality on entrepreneurial activity (Bosma, Content, Sanders, \& Stam, 2018) and the impact of entrepreneurial activity on existing institutions - if any have been studied in isolation, at least empirically.

The matter of institutions in economic growth has gained much consideration from scholars, both hypothetically and empirically. Acemoglu, Johnson, and Robinson (2005) state that institutions are the fundamental causes of economic growth, and only these fundamental causes can explain why a few nations are wealthier and develop quicker than others. A similar idea was proposed regarding entrepreneurship. According to Sautet (2005), the abundance and absence of entrepreneurship are not the main reasons for development and developmental lag, respectively. Baumol (1990) suggests that it is not the offer of entrepreneurship but the rules that undergo significant changes. Considering entrepreneurship is never scarce, why has it developed much more in some countries than in others? As institutions matter for economic growth, they are also important for entrepreneurial activity. Institutions create incentives for key economic actors (Acemoglu et al., 2005). As one of the key actors in society, entrepreneurs are also motivated by supportive institutions. Differences in institutional quality offer distinct incentives to engage in various entrepreneurial activities. Since entrepreneurship is the creation and discovery of new and differentiated products (Sine \& David, 2010; Sautet, 2005), institutions determine under what conditions entrepreneurs can use available resources to conduct business (Bosma et al., 2018). Changes to this set of rules lead to the emergence of productive, unproductive, or destructive entrepreneurial activity (Baumol, 1990).

The relationship between the institutional theory and entrepreneurship remains unclear and lacking in relevant research, with few researchers investigating this theoretical relationship (Hwang \& Powel, 2005; Sine \& David, 2010). Some recent studies develop a theoretical approach to examine twoway causal relationships between institutions and entrepreneurship, showing how institutions support entrepreneurial activity and how institutional entrepreneurs change and build new supportive institutions. To study the impact of institutions on entrepreneurship, three dimensions of institutions are used: regulative, normative, and cultural-cognitive (Scott, 2008). Most empirical studies use simple least squares regression methods to test the correlation between institutions and entrepreneurship and the impact of these two factors on economic growth (Bjornskov \& Foss, 2013; Bosma et al., 2018; Stam \& Van Stel, 2011; Urbano \& Aparicio, 2016). However, not many scholars have used the structural equation modelling (SEM) approach. One exception is Castano-Martinez et al. (2015), who use the SEM method to estimate the effect of different policy remedies on entrepreneurial activity to advance growth. However, they limit their study to 13 European countries for 2012.

This article empirically examines the causal associations of institutions and entrepreneurship in 19 OECD (Organization for Economic Co-operation and Development) countries over the 2014-2016 period. To our best knowledge, a limited amount of experiential work has highlighted the impact of entrepreneurship on institutions or causal relationships between them. Recently, Samadi (2019) has studied the causality of institutions and entrepreneurship by applying the Granger causality test. However, most previous empirical studies that test the link between institutions and entrepreneurship focused on the impact transmitted from institutions to entrepreneurship. Nevertheless, the emergence of new players and institutional entrepreneurs, such as large firms and professional associations, modify existing institutions or build new ones (Greenwood, Suddaby, \& Hinings, 2002). In this regard, ours is one of the first empirical studies to examine the impact of entrepreneurship on institutions.

For our test, we apply the structural equation modelling (SEM) method to find an interrelated association between the institutional environment and entrepreneurial activity in OECD countries. Countries gathered in the OECD have more developed institutions and are considered the best places for entrepreneurship compared to other countries. Moreover, the OECD provides an environment in which countries around the world can compare policy experiences and find answers for common socioeconomic problems (usoecd.usmission.gov). Testing our hypothesis in OECD countries provides a good example for other countries. All the above motivated us to conduct research on the example of OECD countries. 
Section two summarises the theoretical background and literature review on this topic, along with the proposed hypotheses. Section three presents our data and models. Section four outlines the estimation results and discussions, and section five provides concluding remarks.

\section{LITERATURE REVIEW AND HYPOTHESES DEVELOPMENT}

Over the past few decades, institutions-as a set of rules-have gained increasingly more attention from scholars. Distinguished scholars of new institutional economics such as Coase (1998), North (1990), Williamson (2000), and Acemoglu et al. (2005) note the importance of institutions in economic development. Menard and Shirley (2011) mention that there are two prominent schools of thought in the study of modern institutional economics: one of Coase and Williamson, which focuses on property rights and contracts, and the other of North, which emphasises the role of the state and institutional environment. Coase (1937) notes that low transaction costs and clearly defined property rights help overcome the problem of externalities. North (1990) argues that institutions as a set of rules play a key part in maintaining order and security in society. He develops a framework for institutional change and applies it to the problems of economic development (North, 1992). According to Williamson (1985), institutions with low transaction costs coordinate the relationship between individuals and groups (Herath, 2005). Considering their role as fundamental causes of economic growth and development, only institutions may explain the differences in income distribution and influence the structure of economic incentives for individuals to save, invest, and innovate (Acemoglu et al., 2005).

\section{From institutions to entrepreneurship}

Most previous studies in institutional economics largely ignore the role of institutions in entrepreneurship (Sine \& David, 2010). However, recently, voluminous studies have focused on examining the effect of institutional environment on entrepreneurship (Angulo-Guerrero, Perez-Moreno, \& Abad-Guerrero, 2017; Aparicio, Urbano, \& Audretsch, 2016; Castano-Martinez, Mendez-Picazo, \& Galindo-Martin, 2015; Williams \& Vorley, 2015; Muralidharan \& Pathak, 2016; Fuentelsaz, Gonzalez, \& Maicas, 2018). As mentioned above, this approach creates an unclear relationship between institutions and entrepreneurship and requires uncovering how institutional environment can influence entrepreneurial activity. Baumol (1990) proposes that institutions might influence the allocation of entrepreneurship but not its supply. Hwang and Powell (2005) study the part of institutions in the advancement of entrepreneurship and argue that changes in the institutional environment create great opportunities for entrepreneurs. Cultural-cognitive, normative, and regulative dimensions of institutional environments (Scott, 2008) relate to entrepreneurship and shape the entrepreneurial process, creating certain opportunities and obstacles for entrepreneurs (Sine \& David, 2010; Tolbert et al., 2011). Institutions create entrepreneurial choices via the following steps: a) founding new organizations by providing individuals with new opportunities to enter market activities; b) introducing decision-making processes on how to design new organizations; and c) managing external relations with partners (Tolbert et al., 2011). In general, institutions give the right guidance to the entrepreneurs and, most importantly, reduce the uncertainty in their social interactions (Sautet, 2005).

Although it is difficult to measure and choose the correct proxies of institutional environment, several empirical works have been conducted to examine their effect on entrepreneurship. Bosma et al. (2018) study the impact of regulatory, cognitive, and normative measures of institutions on different indicators of entrepreneurship and, in turn, summarise several previously relevant empirical articles that investigate the association of various indicators of institutional dimensions and entrepreneurship. Nissan, Galindo and Picazo (2012) and De Clercq, Danis, and Dakhli (2010) examine the influence of the normative dimension of institutions on entrepreneurial activity. Meanwhile, Van Stel, Storey, and Thurik (2007), Bjornskov and Foss (2008), and De Clercq et al. (2010) test the impact of the regulatory dimension of institutions on entrepreneurship. Castano-Martinez et al. (2015) find that the role of the regulative and cognitive dimensions of institutions is significant in explaining entrepreneurship. 
The normative dimension emphasises a deeper moral base for legitimacy and includes norms and values (Scott, 2008). Norms and values indicate what is "good" or "appropriate" to evaluate entrepreneurial activity (Sine \& David, 2010). According to Castano-Martinez et al. (2015), socially recognised entrepreneurial achievements play a part in the development of new entrepreneurs. The more we value entrepreneurship, the more entrepreneurs appear in the economy. Considering the normative institutional environment, De Clercq et al. (2010) develop five questions for an expert questionnaire to determine whether entrepreneurship is a good career choice. Based on these discussions, we propose our first hypothesis:

H1: The high value of entrepreneurship has a positive impact on entrepreneurial activity.

The regulative measure of institutions includes rules, laws, and sanctions (Scott, 2008). Supportive regulatory regimes give impetus to entrepreneurship, while hostile regulations suppress its development (Sine, David, \& Mitsuhashi, 2007; Sine \& David, 2010). Numerous studies have analysed the impact of regulatory regimes on entrepreneurial activity (Van Stel et al., 2007; Bjornskov \& Foss, 2008; De Clercq et al., 2010; Bosma et al., 2018). Bjornskov and Foss (2008) use indicators of the Economic Freedom Index to examine the effect of the regulatory environment of institutions on entrepreneurship.

Moreover, regulatory regimes are important in explaining economic growth. As noted above, recent studies in institutional economics consider the regulatory environment of institutions as fundamental causes of economic growth and development, and only regulatory regimes can explain why some countries are wealthier and grow faster than other countries (Acemoglu et al., 2005). According to them, this is due to the incentive-creating nature of economic and political institutions. However, this only happens under the high quality of economic institutions. This leads to our next hypothesis:

H2: An economically free society has a positive impact on the prosperity of entrepreneurial activity and economic growth.

Entrepreneurship has been emphasised as one of the primary factors of economic progress. Its role in economic prosperity is explained through its innovative effect on economic performance. The entrepreneurship theory argues that, as a channel of knowledge spillover, it provides the most important apparatus to economic prosperity (Audretsch, Keilbach, \& Lehmann, 2006). The proponent of the entrepreneurship theory, Joseph Schumpeter (1934), considers the importance of entrepreneurship due to its innovative nature in the process of economic progress. Bosma et al. (2018) provide a summary of recent empirical studies on the effect of entrepreneurship on economic growth. Braunerhjelm, Acs, Audretsch, and Carlsson (2010) and Castano-Martinez et al. (2015) find positive entrepreneurshipgrowth correlations by applying Romer's production function and the structural equation model, respectively. Consequently, we set forth the following hypothesis:

H3: Entrepreneurship has a positive impact on economic prosperity.

We also include human capital as a control variable to account for alternative explanations of entrepreneurial activity and economic growth. Endogenous growth theory argues that human capital is a central component of long-run economic growth. However, achieving long-run economic prosperity requires large investments in human capital, innovation, and knowledge. A pioneer of the endogenous growth theory, Romer (1990) argues that the supply of human capital determines long-term growth by increasing the knowledge of the population. Human capital is an important source of innovation due to spillover effects. According to Acs, Braunerhjelm, Audretsch, and Carlsson (2009), the spillover effect of knowledge is important for creating a set of technological opportunities. They argue that knowledge spillovers stimulate entrepreneurial activity and is a vital source of economic growth.

Moreover, the importance of human capital for economic prosperity - as a source of innovation leads to investment in human capital. Moog (2002) and Cassar (2006) argue that human capital investment has a significant impact on the growth of start-ups, finding that start-ups with highly educated founders are much more successful compared to those with less-educated founders. Differences in 
experiences, knowledge, and skills of individuals explain the speed at which they explore and use entrepreneurial openings (Shane \& Venkataraman, 2000). Better education helps transform entrepreneurial opportunities into a real business and makes entrepreneurship flourish (Reynold, Hay, \& Camp, 1999). This leads to our next hypothesis:

H4: Human capital has a positive impact on entrepreneurship and growth.

\section{From entrepreneurship to institutions}

Thus far, institutional and entrepreneurial research - mostly empirical - has drawn attention to the one-way association of institutions and entrepreneurial activity, in which institutions explain entrepreneurial activity in the economy. However, recent studies on institutions and entrepreneurship are increasingly drawing attention to entrepreneurs as reformers of existing institutional environments (Sine \& David, 2010; Kuchar, 2016; Fuentelsaz, Gonzalez, Maicas, \& Montero, 2015). Actors that modify current institutions and build new ones are called "institutional entrepreneurs" (Beckert, 1999; Maguire, Hardy, \& Lawrence, 2004; Greenwood et al., 2002). According to Sine and David (2010), entrepreneurs change or modify existing institutions through theorizing, integrating, and exteriorizing activities. Theorization concerns constructing a new set of problems and solutions; integration is the addition of new practices and ideas to existing institutional orders; and exteriorizing refers to experiencing a new set of ideas as a natural part of the environment (Sine \& David, 2010). Hwang and Powell (2005) study how new experiences and structures become institutionalised.

There are several examples of how professionals - as key institutional entrepreneurs - modify existing institutions. Back in the sixteenth and seventeenth centuries, the rise of the Atlantic trade steadily empowered the de facto role of merchants in England by constraining the power of the king. This helped merchants alter existing institutions to strengthen their property rights (Acemoglu et al., 2005). The role of influential chefs, who gave birth to French gastronomy in the nineteenth century, is another example of how professionals performed a key part within the rise of new institutions (Ferguson, 2004; Hwang \& Powell, 2005). These discussions lead us to develop our next hypotheses:

H5: A society with developed entrepreneurial activity has a positive impact on the status of entrepreneurs.

H6: Entrepreneurship has a positive influence on the improvement of economic freedom.

\section{RESEARCH METHODOLOGY}

\section{Model specifications}

In this study, we apply structural equation modelling (SEM) to examine our hypotheses. The SEM method is a combination of factor analysis and regression, which enables users to find causal associations of latent variables. The strength of SEM is that it allows us to simultaneously test measurement and structural models and provide direct and indirect effects (Bullock, Harlow, \& Mulaik, 1994). Furthermore, the SEM method enables theory testing and development and provides an assessment of the relativity of hypotheses to the concerned theory (Bullock et al., 1994; Barclay, Higgins, \& Thompson, 1995). This process is conducted by examining the consistency of measures and evaluating the associations between given latent variables (Barclay et al., 1995). Besides, when researchers use the SEM, they can find an answer to a number of interconnected research questions in several types of analyses by modelling the relationship between several constructs simultaneously.

The SEM comprises of measurement (or outer) and structural (or inner) models. The structural model part relates all exogenous and endogenous latent or unobserved variables to one another. As shown in Figure 1, the structural model part of our general model has both recursive models (one-way causality) and non-recursive models (two-way causality). 


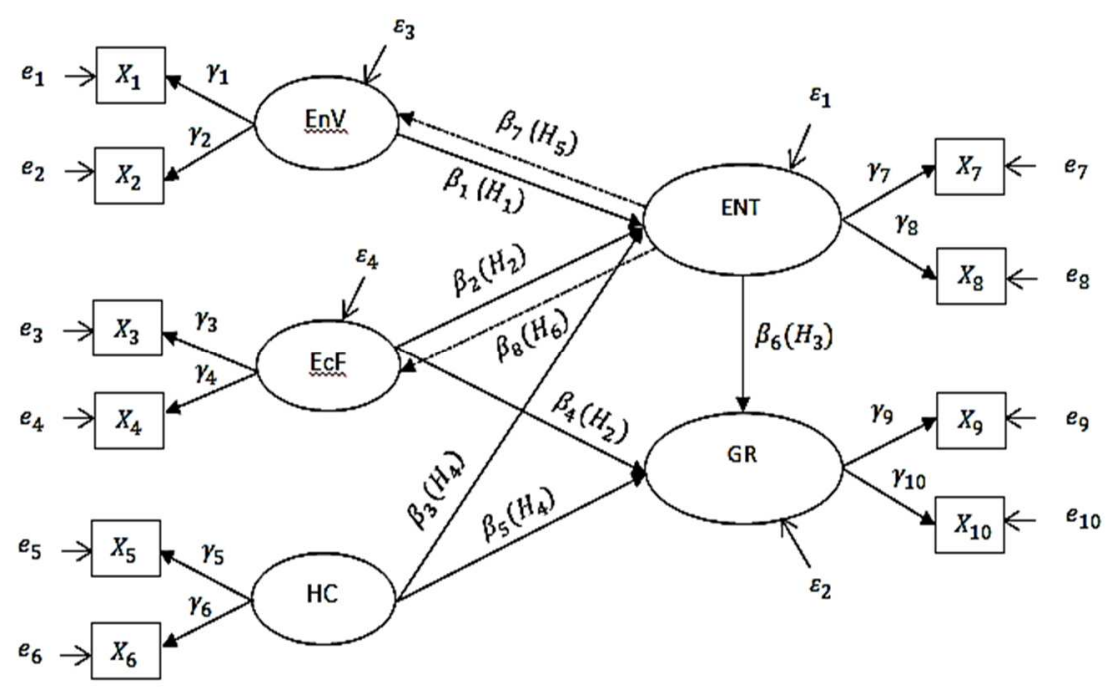

Figure 1. The Structural Equation Model

Source: own elaboration.

For our example, the matrix representation of the structural model is given below:

$$
\left[\begin{array}{c}
E N T \\
G R \\
E n V \\
E c F
\end{array}\right]_{4 \times 1}=\left[\begin{array}{cccc}
\beta_{1} & \beta_{2} & \beta_{3} & 0 \\
0 & \beta_{4} & \beta_{5} & \beta_{6} \\
0 & 0 & 0 & \beta_{7} \\
0 & 0 & 0 & \beta_{8}
\end{array}\right]_{4 \times 4}\left[\begin{array}{c}
E n V \\
E c F \\
H C \\
E N T
\end{array}\right]_{4 \times 1}+\left[\begin{array}{c}
\varepsilon_{1} \\
\varepsilon_{2} \\
\varepsilon_{3} \\
\varepsilon_{4}
\end{array}\right]_{4 \times 1}
$$

The measurement model links observed variables to latent variables. There are two different types of measurement models: a) formative, in which observed variables cause latent variables, and b) reflective, in which observed variables reflect latent variables. In this study, our measurement models are reflective (Figure 1). The matrix form of the model is shown below:

$$
\left[\begin{array}{c}
X_{1} \\
X_{2} \\
X_{3} \\
\vdots \\
X_{10}
\end{array}\right]_{10 \times 1}=\left[\begin{array}{ccccc}
\gamma_{1} & 0 & 0 & 0 & 0 \\
\gamma_{2} & 0 & 0 & 0 & 0 \\
0 & \gamma_{3} & 0 & 0 & 0 \\
\vdots & \vdots & \vdots & \vdots & \vdots \\
0 & 0 & 0 & 0 & \gamma_{10}
\end{array}\right]_{10 \times 5} \quad\left[\begin{array}{c}
E n V \\
E c F \\
H C \\
E N T \\
G R
\end{array}\right]_{5 \times 1}+\left[\begin{array}{c}
e_{1} \\
e_{2} \\
e_{3} \\
\vdots \\
e_{10}
\end{array}\right]_{10 \times 1}
$$

We use the partial least squares (PLS) regression approach. Currently, PLS regression is often used in various research fields to estimate structural equation models. In this regard, PLS has a specific advantage over ML and GLS estimation. First, unlike in ML or GLS estimation, multivariate normality assumption can be relaxed in PLS (Barclay et al., 1995). Second, experience shows that PLS regression is the right estimation method of complex causal models built on small-size data and many observable and latent variables (Barclay et al., 1995; Henseler, Ringle, \& Sinkovics, 2009; Tenenhaus, 2008). Third, the SEM method has simple systematic convergence, which allows users to apply it easily (Tenenhaus, 2008). Finally, PLS regression is an appropriate method of estimation for both formative and reflective models (Henseler et al., 2009).

\section{Data}

We restrict our analysis to 19 member countries of the OECD for 2014-2016, as data are not available for all member countries (Australia, Chile, Estonia, Finland, Germany, Greece, Hungary, Ireland, Italy, Luxembourg, Netherlands, Poland, Portugal, Slovakia, Slovenia, Spain, Sweden, Switzerland, the United Kingdom). For the estimation purposes, the data are taken from different open sources, including the World Bank open data, the United Nations Human Development Data (UNDP HDR), the Fraser 
Institute's Economic Freedom data, and GEM (Global Entrepreneurship Monitor). We include the normative and regulative dimensions of institutions in our analysis to check the effect of institutions on entrepreneurial activity and vice versa.

As a normative dimension of institutions, we take entrepreneurial value data from the GEM. Data on economic freedom as the measure of the regulatory measure of institutions are derived from the Fraser Institute Economic Freedom data. Indicators of entrepreneurship are also taken from the GEM. Table 1 below provides a complete overview of our latent and observed variables with definitions and sources of data.

The GEM collects primary entrepreneurship data based on large-scale Adult Population Surveys of individuals aged 18-64 in each GEM economy and provides a complete set of entrepreneurship indicators (Bosma \& Kelley, 2019). Thus, the GEM is considered a unique source of data for entrepreneurship researchers.

Table 1. Constructs, measures, and sources of data

\begin{tabular}{|c|c|c|}
\hline Latent variables & Observed variables and definitions & Source \\
\hline \multirow[t]{2}{*}{$\begin{array}{l}\text { Entrepreneurial } \\
\text { Value (EnV) }\end{array}$} & $\begin{array}{l}\text { High status of successful entrepreneurs' rate }\left(X_{1}\right)-\text { the ratio of population } \\
\text { aged } 18-64 \text { who admit that prosperous entrepreneurs achieve high posi- } \\
\text { tions. }\end{array}$ & \multirow[t]{2}{*}{ GEM } \\
\hline & $\begin{array}{l}\text { Entrepreneurship as a good career choice rate }\left(X_{2}\right)-\text { the ratio of popula- } \\
\text { tion aged 18-64 who admit that doing a business is a good choice of job. }\end{array}$ & \\
\hline \multirow{2}{*}{$\begin{array}{l}\text { Economic } \\
\text { Freedom } \\
\text { (EcF) }\end{array}$} & $\begin{array}{l}\text { Legal quality }\left(X_{3}\right) \text { - the quality of protection of people and their legally } \\
\text { acquired property }\end{array}$ & \multirow{2}{*}{$\begin{array}{l}\text { Fraser Institute } \\
\text { Economic Free- } \\
\text { dom project }\end{array}$} \\
\hline & $\begin{array}{l}\text { Regulatory efficiency }\left(X_{4}\right) \text { - the efficiency of credit, labor market regula- } \\
\text { tions, and business regulations }\end{array}$ & \\
\hline \multirow{2}{*}{$\begin{array}{l}\text { Human } \\
\text { Capital (HC) }\end{array}$} & Log of mean years of schooling $\left(X_{5}\right)$. & \multirow[t]{2}{*}{ UNDP HDR } \\
\hline & $\begin{array}{l}\text { Log of population with at least some secondary education (\% of people } \\
\text { aged } 25 \text { and older) }\left(X_{6}\right) \text {. }\end{array}$ & \\
\hline \multirow[t]{2}{*}{$\begin{array}{l}\text { Entrepreneurship } \\
\text { (ENT) }\end{array}$} & $\begin{array}{l}\text { Entrepreneurial employee activity rate }\left(X_{7}\right) \text { - the degree of employee in- } \\
\text { volvement in entrepreneurship. }\end{array}$ & \multirow[t]{2}{*}{ GEM } \\
\hline & $\begin{array}{l}\text { Motivation index }\left(X_{8}\right) \text { - the ratio of people in TEA who are interested in } \\
\text { improving opportunities. }\end{array}$ & \\
\hline \multirow[t]{2}{*}{ Growth (GR) } & Log of GDP per capita (PPP) $\left(X_{9}\right)$. & World Bank \\
\hline & $\begin{array}{l}\text { Log of employment to population ratio (percentage of people aged } 15 \text { or } \\
\text { older) }\left(X_{10}\right) \text {. }\end{array}$ & UNDP HDR \\
\hline
\end{tabular}

Source: own study.

\section{RESULTS AND DISCUSSIONS}

\section{From institutions to entrepreneurship}

The proper evaluation of interrelated measurement and structural models leads to the correct conclusion about the hypothesised relationship between latent variables. The interpretation of PLSbased SEM results was conducted through the evaluation of the robustness of the outer model, followed by the evaluation of the inner model (Fornell \& Lacker, 1981; Barclay et al., 1995). Although PLS has less extensive statistics (Gefen, Straub, \& Boudreau, 2000), specific conclusions could have been drawn from the results. The additional statistics of Cronbach's alpha, average variance extracted (AVE), composite reliability, and individual item consistency assessed the robustness of constructs' measures in the PLS regression.

As the first step in analysing the PLS structural equation model is to evaluate the measurement model, we began by assessing the consistency of the measurements before inferring the association between constructs. In this regard, we first examined individual item consistency by studying the loadings of the observed variables. Scholars suggest 0.7 as the minimum acceptable threshold for individual item reliability (Barclay et al., 1995; Carmines \& Zeller, 1979). In our example, the second variable $\left(X_{2}\right)$ of entrepreneurial value was far from the suggested minimum threshold and seemed an unreliable 
measure of entrepreneurial value (Table 2). Three potential reasons for the low loadings were as follows. First, measures are simply unreliable; the second reason refers to methods effect, while the third lies in the multidimensionality of constructs (Barclay et al., 1995). Not knowing the exact reason for this low loading, we decided to drop item $X_{2}$ from entrepreneurial value. Moreover, since our hypothesised model was a reflective measurement model, individual items would be interchangeable, and any single item can generally be removed without changing the meaning of the construct (Jarvis, Mackenzie, \& Podsakoff, 2003). According to previous studies, the use of a single item can be successful in many circumstances when applying SEM modelling (Petrescu, 2013).

Table 2. Loadings and cross-loadings of measures (the hypothesised model)

\begin{tabular}{|l|c|c|c|c|c|}
\hline \multicolumn{1}{|c|}{ Variables } & EnV & EcF & HC & ENT & GR \\
\hline$X_{1}$ & 0.891 & 0.402 & 0.408 & 0.355 & 0.384 \\
\hline$X_{2}$ & -0.708 & -0.306 & -0.507 & -0.228 & -0.318 \\
\hline$X_{3}$ & 0.502 & 0.925 & 0.382 & 0.782 & 0.824 \\
\hline$X_{4}$ & 0.307 & 0.911 & 0.558 & 0.696 & 0.787 \\
\hline$X_{5}$ & 0.548 & 0.557 & 0.957 & 0.530 & 0.645 \\
\hline$X_{6}$ & 0.477 & 0.385 & 0.932 & 0.440 & 0.509 \\
\hline$X_{7}$ & 0.297 & 0.773 & 0.531 & 0.909 & 0.831 \\
\hline$X_{8}$ & 0.366 & 0.616 & 0.350 & 0.831 & 0.608 \\
\hline$X_{9}$ & 0.472 & 0.738 & 0.440 & 0.621 & 0.808 \\
\hline$X_{10}$ & 0.256 & 0.709 & 0.573 & 0.758 & 0.838 \\
\hline
\end{tabular}

Source: own study.

As a gauge of the internal consistency of the measurements, we used Cronbach's alpha and composite reliability statistics. These are the most widely used measures of reliability. The minimum threshold of Cronbach's alpha for internal consistency is 0.6 for exploratory research (Nunnally, 1967) and 0.7 for confirmatory research (Nunnally, 1978; Nunnally \& Bernstein, 1994). However, most recent studies accept 0.7 as an appropriate lower threshold to evaluate reliability (Cortina, 1993). In the case of composite reliability without an exact criterion, 0.7 is often considered the minimum reliability threshold (Segars, 1997). In our example, our first construct - entrepreneurial value - had inconsistencies regarding these two measures. We were able to improve composite reliability by dropping an unreliable measure. This confirmed our decision for removing the second item $\left(X_{2}\right)$ of entrepreneurial value in the ensuing analysis. Furthermore, the removal of $X_{2}$ increased the composite reliability, Cronbach's alpha, and AVE of the respective measurement model. However, the value of Cronbach's alpha is positively correlated with the number of measures, meaning an increment within the number of items leads to an increment in Cronbach's alpha (Hair, Black, Babin, \& Anderson, 2010). Thus, the Cronbach's alpha of growth construct fell below the suggested minimum threshold of 0.7 , but its composite reliability was well above the benchmark level of 0.7 . The other three remaining constructs had a satisfactory degree of consistency (Table 3).

Table 3. Construct reliability and validity (the hypothesised model)

\begin{tabular}{|l|c|c|c|c|c|c|c|c|}
\hline \multirow{2}{*}{ Variables } & \multirow{2}{*}{ AVE } & \multirow{2}{*}{ Composite reliability } & \multirow{2}{*}{ Cronbach's $\boldsymbol{\alpha}$} & \multicolumn{5}{|c|}{ Correlation of Constructs* } \\
\cline { 5 - 9 } & & & & EnV & EcF & HC & ENT & GR \\
\hline EnV & 0.647 & 0.123 & -0.898 & 0.805 & & & & \\
\hline EcF & 0.843 & 0.915 & 0.814 & 0.445 & 0.918 & & & \\
\hline HC & 0.892 & 0.943 & 0.881 & 0.545 & 0.508 & 0.945 & & \\
\hline ENT & 0.758 & 0.862 & 0.687 & 0.373 & 0.806 & 0.518 & 0.871 & \\
\hline GR & 0.677 & 0.808 & 0.524 & 0.437 & 0.878 & 0.618 & 0.840 & 0.823 \\
\hline
\end{tabular}

* Diagonal elements in the "correlation of constructs" matrix are the square roots of average variance extracted (AVE). Source: own study.

The AVE assesses the convergent validity of the measurement models (Gefen et al., 2000; Hair et al., 2010). An AVE value of less than 0.5 casts doubt on the validity of individual measures (Fornell \& 
Larcker, 1981). This validity test results showed measurements with a satisfactory degree of convergent validity. Table 3 above demonstrates the reliability and validity statistics.

The next statistics of consistency was discriminant validity. There are several criteria for assessing the discriminant validity of PLS-based SEM. One is cross-loadings of items, while another involves the Fornell and Larcker criterion. According to cross-loadings of indicator criteria, indicators should have more loadings on the assigned constructs than on other constructs. All given variables satisfied this criterion (Table 2). Based on the second criterion of discriminant validity assessment the Fornell and Larcker criterion - the square root of the AVE of a certain construct should be greater compared to correlation with other constructs (Barclay et al., 1995; Gefen et al., 2000; Hair et al., 2010). Thus, when the square root of AVE is greater than the off-diagonal elements, discriminant validity of our sample would be appropriate. In our sample, there was some controversy in the case of economic freedom-growth and entrepreneurship-growth constructs. However, in both cases, the bias was very small: 0.055 and 0.017 , respectively (Table 3 ). In general, this assessment further supported the discriminant validity of measurement models.

Once the consistency of the measurement models was ensured, we evaluated the structural model. For this, PLS provides a bootstrapping method to obtain the necessary statistics. Based on these statistics, we evaluated the hypothesised associations the constructs.

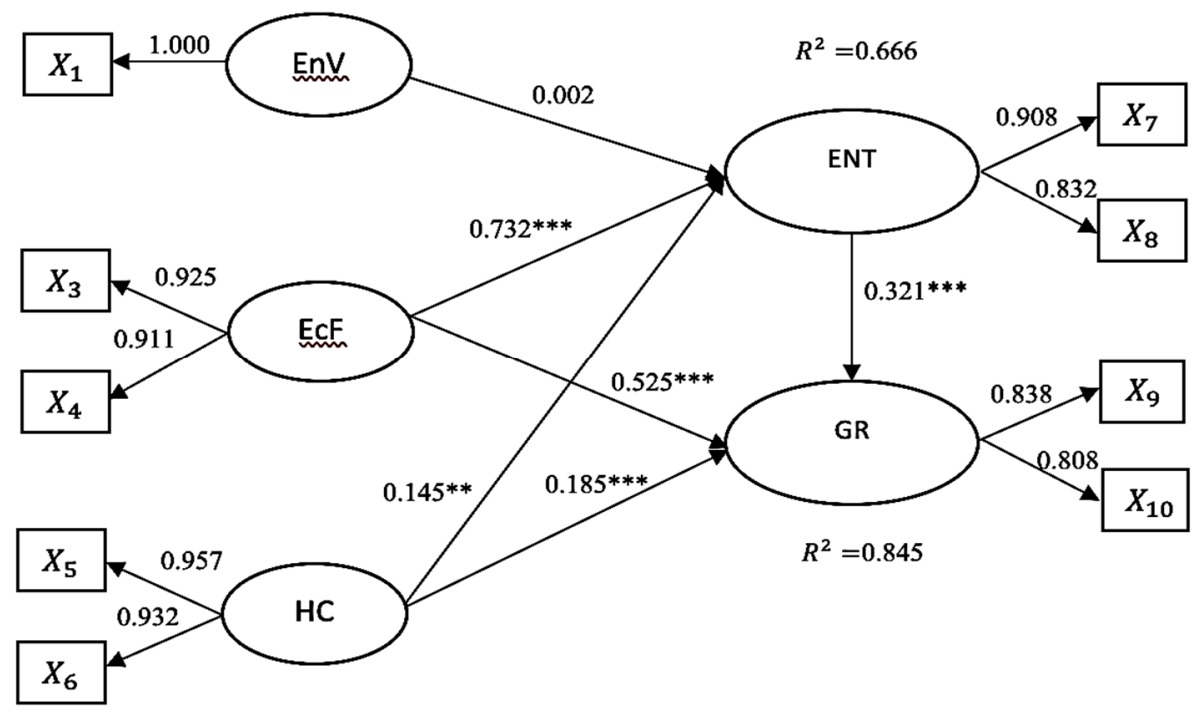

Figure 2. PLS algorithm results (final model) $* * * p<0.01 ; * * p<0.05$. Source: own elaboration.

Accordingly, Table 4 below presents the outcomes of bootstrapping, which shows the results of our analysis. Based on the given statistics, Hypothesis $\mathrm{H} 1$ was not supported due to an insignificant path coefficient $\left(\beta_{1}=0.002\right)$ at the $5 \%$ significance level. Thus, it seems that the value of entrepreneurship is not the driving force behind entrepreneurship for this group of countries. This finding does not support the findings of previous studies in which the normative dimension of institutions was an important driver of entrepreneurship (Stephan \& Uhlaner, 2010; Danis, De Clercq, \& Petricevic, 2011; Bosma et al., 2018).

Hypothesis $\mathrm{H} 2$ was confirmed with significant and positive path coefficients $\left(\beta_{2}=0.732\right.$ and $\beta_{4}=0.525$ ) at an appropriate significance level. This proves the idea that improvements in economic freedom promote entrepreneurial activity and lead to the economic prosperity of society. Consequently, these results are in line with the findings of De Clercq et al. (2010), Castano-Martinez et al. (2015), and Bosma et al., (2018). Moreover, the finding of a relationship between economic freedom and growth is consistent with the findings of Brkich (2020), who finds that improved economic freedom leads to economic growth in European countries.

Similarly, we examined whether Hypothesis $\mathrm{H} 3$ is significant. Obtained path coefficients verified that Hypothesis 3 had the same significance level $\left(\beta_{6}=0.321\right)$. This confirms that entrepreneurial ac- 
tivity positively affects economic prosperity. Furthermore, this finding confirms the hypotheses of previous studies that entrepreneurship positively impacts growth (Castano-Martinez et al., 2015; Aparicio et al., 2016 and Bosma et al., 2018).

Table 4. Path coefficients of the SEM approach (final model)

\begin{tabular}{|l|c|c|c|c|}
\hline \multicolumn{1}{|c|}{ Relations } & Original Sample (O) & Sample Mean (M) & Standard Deviation (STDEV) & $t$-statistics \\
\hline EnV -> ENT & 0.002 & 0.002 & 0.090 & 0.022 \\
\hline ECF -> ENT & $0.732^{* * *}$ & 0.741 & 0.059 & 12.309 \\
\hline ECF -> GR & $0.525^{* * *}$ & 0.526 & 0.089 & 5.916 \\
\hline HC $>$ ENT & $0.145^{* *}$ & 0.139 & 0.072 & 2.006 \\
\hline HC $>$ GR & $0.185^{* * *}$ & 0.187 & 0.057 & 3.249 \\
\hline ENT $>$ GR & $0.321^{* *}$ & 0.319 & 0.102 & 3.161 \\
\hline
\end{tabular}

*** $\mathrm{p}<0.01 ; * * \mathrm{p}<0.05 ; \mathrm{R} 2$ for ENT $=0.666$; R2 for $\mathrm{GR}=0.845$.

Source: own study.

Table 5. Direct, indirect, and total effects between constructs (final model)

\begin{tabular}{|l|c|c|c|}
\hline \multicolumn{1}{|c|}{ Relations } & Direct Effect & Indirect Effect & Total Effect* \\
\hline EnV $>$ ENT & 0.002 & & 0.002 \\
\hline EnV -> GR & & -0.016 & 0.732 \\
\hline EcF - ENT & 0.732 & & 0.760 \\
\hline EcF - G GR & 0.525 & 0.235 & 0.145 \\
\hline HC - ENT & 0.145 & & 0.232 \\
\hline HC - > GR & 0.185 & 0.047 & 0.321 \\
\hline ENT -> GR & 0.321 & & \\
\hline
\end{tabular}

* Total effect $=$ Direct Effect + Indirect Effect

Source: own study.

Moreover, our statistics proved Hypothesis $\mathrm{H} 4$. Obtained path coefficients $\left(\beta_{3}=0.145\right.$ and $\beta_{5}=$ 0.185 ) with significant $t$ values verified positive and significant relations of human capital and entrepreneurship with economic growth. This means that the economies with highly developed human capital contribute to the development of entrepreneurship. This is further corroborated by the results of Moog (2002), Kassar (2006), and many others, who state that skilled and educated people are more successful in entrepreneurial activities. Moreover, countries with higher investment in human capital achieve higher levels of economic growth. This finding supports and agrees with those of Pelinescu (2015), who finds that innovative and skilled human capital drive economic growth.

The $R$-squared value as a percentage measure of variance explains percentage variance in the endogenous latent variables due to exogenous variables. The values of $R^{2}$ indicate that a $67 \%$ change in entrepreneurship and an $85 \%$ change in economic growth is explained by our model, which is very significant.

Moreover, PLS regression generates indirect and total effects of developed constructs (Table 5). In the case of economic freedom and human capital, their total effect on entrepreneurship is equal to their direct effect (path coefficients) as no indirect effect is predicted. Similarly, entrepreneurship too has only a direct effect on growth equal to its total effect. However, economic freedom and human capital have both direct and indirect effects on economic growth, while their sum is equal to their total effect on growth.

\section{From entrepreneurship to institutions}

As PLS regression cannot estimate reciprocal (two-way) causation in a single test, we separately estimate the other causality that moves from entrepreneurship to institutions. As mentioned above, the first step in analysing the PLS-based SEM is the assessment of the consistency of the measurement model. In this respect, in the case when the impact was transmitted from entrepreneurship to institutions, we also first examined the consistency of observable variables by studying their loadings with corresponding latent variables. Since we worked with the same measures and 
constructs in two cases, the reliability and validity assessment results of the measurement models were the same. As discussed in the first part of the discussion, only the second variable $\left(X_{2}\right)$ of entrepreneurial value seemed invalid because its value exceeded the recommended minimum threshold of 0.7 . Due to this unreliable indicator, the consistency of the construct of entrepreneurial value did not satisfy the minimum thresholds, which motivated us to abandon the $X_{2}$ item. In the following analysis, we generated results without this variable.

Then, we turned to the analysis of path coefficients. The PLS algorithm resulted from the general structural equation model, in which the effect was transferred from entrepreneurship to institutions as presented in Figure 3.

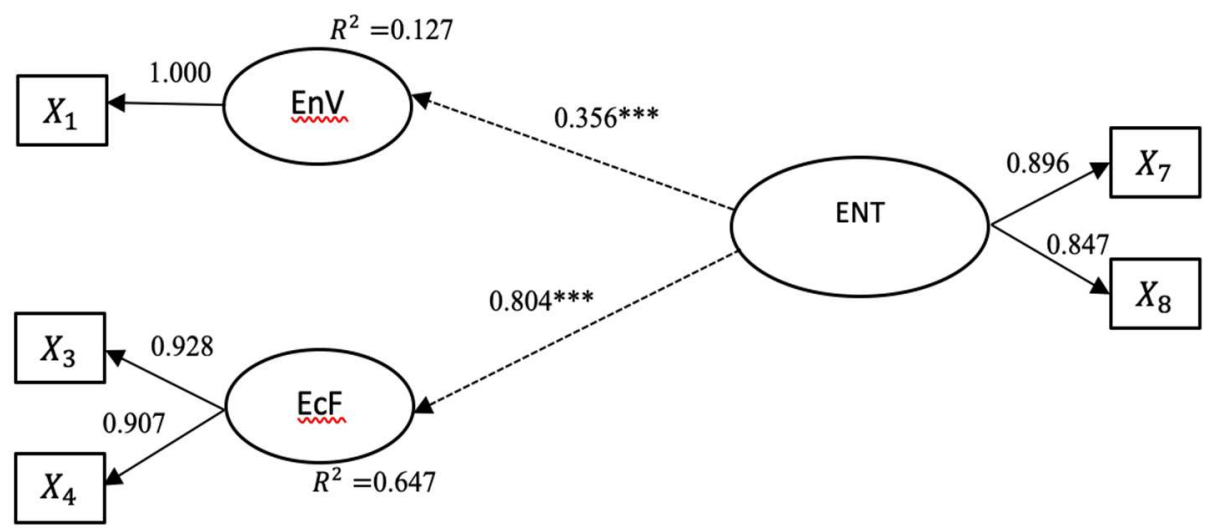

Figure 3. PLS algorithm results (final model) $* * * p<0.01$

Source: own elaboration.

Thereafter, Table 6 demonstrates the outcomes of bootstrapping. According to available path coefficients, entrepreneurial activity thus appeared statistically significant and positively affecting entrepreneurial value in society $\left(\beta_{7}=0.356\right)$. This proves the expectation that a high degree of entrepreneurship leads to an improvement in the status of entrepreneurs. This result is consistent with the point of Tolbert et al. (2011) and findings of Kuchar (2016) who notice that entrepreneurs as institutional agents affect and change institutions. These findings helped us conclude that entrepreneurial value and entrepreneurship have a one-way relationship, not a causal two-way relationship, thus proving hypothesis $\mathrm{H} 6$.

A significant and positive path coefficient $\left(\beta_{8}=0.804\right)$ confirmed our expectation that entrepreneurs can also modify existing regulatory environments and serve as a driving force for economic freedom. According to the obtained value of the $R^{2}$, a $65 \%$ variance in economic freedom was explained by the model. Consequently, this result is consistent with the points of Sine and David (2010) and the results of Samadi (2019) who declare that entrepreneurs are important in creating a friendly regulatory environment.

Table 6. Path coefficients of the SEM approach (final model)

\begin{tabular}{|l|c|c|c|c|}
\hline \multicolumn{1}{|c|}{ Relations } & Original Sample (O) & Sample Mean (M) & Standard Deviation (STDEV) & $\boldsymbol{t}$-statistics \\
\hline ENT $->$ EnV & $0.356^{* * *}$ & 0.352 & 0.094 & 3.800 \\
\hline ENT -> EcF & $0.804^{* * *}$ & 0.811 & 0.034 & 23.347 \\
\hline
\end{tabular}

$* * * p<0.01 ; \mathrm{R} 2$ for $\mathrm{EnV}=0.127 ; \mathrm{R} 2$ for $\mathrm{EcF}=0.647$.

Source: own study.

In this case, when the effect is transmitted from entrepreneurship to institutions, total effects between constructs equal direct effects (path coefficients) as no indirect effect is predicted.

\section{CONCLUSIONS}

This article sheds light on the study of bidirectional causation between institutions and entrepreneurship. Following our six hypotheses, we tested the link between the two chosen institutional dimensions 
and entrepreneurship and, simultaneously, the impact of the regulatory environment, entrepreneurship, and human capital on economic growth. To empirically test our hypotheses, we chose 19 OECD countries and used a PLS-based structural equation model.

Our empirical results did not prove the hypothesised bidirectional causation between the normative dimension of institutions and entrepreneurship. In our sample, an entrepreneurial value that is a proxy of the normative dimension of institutions has a unidirectional association with entrepreneurship. Thus, a society with developed entrepreneurial activities has a positive effect on the status of entrepreneurs, not vice versa. However, as we expected, the regulatory dimension of institutions and entrepreneurship have a significant bidirectional relationship. The quality of the regulatory environment is highly likely to promote both entrepreneurial activity and economic prosperity. Improvements in the quality of the regulatory environment - such as regulatory efficiency and the rule of law - stimulate entrepreneurship and fuel economic growth. In turn, entrepreneurship also affects the regulatory dimension of institutions. As professionals, entrepreneurs can modify the existing regulatory environment and serve as institutional entrepreneurs. The next important finding is that entrepreneurship proved to be a major driver of economic growth due to its innovative nature. Entrepreneurial societies achieve economic prosperity thanks to their innovative and productive entrepreneurs. Finally, in agreement with previous studies, we also explored that human capital as an important source of innovation creates long-term economic growth. The innovative nature of human capital requires investments. Thus, improving the quality of human capital contributes to the prosperity of entrepreneurship.

As we mentioned above, the greatest contribution of this article is that it is one of the first empirical works devoted to studying bidirectional causality between institutions and entrepreneurship. However, we would not say that we have covered all parts of the research into relations between institutions and entrepreneurship. Instead, our study proposes a new empirical approach to the study of these mutual relations. Given the economic implications of this study, further in-depth research on the correlations of institutions and entrepreneurship is required.

\section{REFERENCES}

Acemoglu, D., Johnson, S., \& Robinson, J.A. (2005). Institutions as the Fundamental Cause of Long-Run Growth. In P. Aghion \& S.N. Durlauf (Eds.), Handbook of Economic Growth (pp. 385-472). Amsterdam: North Holland. https://doi.org/10.1016/S1574-0684(05)01006-3

Acs, Z.J., Braunerhjelm, P., Audretsch, D.B., \& Carlsson, B. (2009). The knowledge spillover theory of entrepreneurship. Small Business Economics, 32, 15-30. https://doi.org/10.1007/s11187-008-9157-3

Angulo-Guerrero, M.J., Perez-Moreno, S., \& Abad-Guerrero, I.M. (2017). How economic freedom affect opportunity and necessity entrepreneurship in the OECD countries. Journal of Business Research, 73, 30-37. https://doi.org/10.1016/j.jbusres.2016.11.017

Aparicio, S., Urbano, D., \& Audretsch, D. (2016). Institutional factors, opportunity entrepreneurship and economic growth: panel data evidence. Technological Forecasting and Social Change, 102, 45-61. https://doi.org/10.1016/j.techfore.2015.04.006

Audretsch, D.B., Keilbach M.C., \& Lehmann, E.E. (2006). Entrepreneurship and Economic Growth. New York: Oxford University Press.

Barclay, D., Higgins, C., \& Thompson, R. (1995). The Partial Least Squares (PLS) Approach to Causal Modelling, Personal Computer Adoption and Use as an Illustration. Technology Studies, Special Issue on Research Methodology, 2(2), 285-309. Retrieved from https://www.researchgate.net/ on August 21, 2019.

Baumol, W.J. (1990). Entrepreneurship: Productive, Unproductive, and Destructive. Journal of Political Economy, 98(5), 893-921. https://doi.org/10.1016/0883-9026(94)00014-X

Beckert, J. (1999). Agency, Entrepreneurs, and Institutional Change. The Role of Strategic Choice and Institutionalized Practices in Organizations. Organization Studies, 20(5), 777-799. https://doi.org/10.1177/0170840699205004

Bjornskov, C., \& Foss, N.J. (2008). Economic freedom and entrepreneurial activity: some cross-country evidence. Public Choice, 134, 307-328. https://doi.org/10.1007/s11127-007-9229-y

Bjornskov, C., \& Foss, N.J. (2013). How Strategic Entrepreneurship and the Institutional Context Drive Economic Growth. Strategic Entrepreneurship Journal, 7(1), 50-69. https://doi.org/10.1002/sej.1148 
Bosma, N., Content, J., Sanders, M., \& Stam, E. (2018). Institutions, Entrepreneurship, and Economic Growth in Europe. Small Business Economics, 51, 483-499. https://doi.org/10.1007/s11187-018-0012-x

Bosma, N., \& Kelley, D. (2019). Global Entrepreneurship Monitor 2018/2019. Global Report. Babson Park, MA, London: Babson College and London Business School. Retrieved from https://www.gemconsortium.org/ on July 24, 2020.

Braunerhjelm, P., Acs, Z.J., Audretsch, D.B., \& Carlsson, B. (2010). The Missing Link: Knowledge Diffusion and Entrepreneurship in Endogenous Growth. Small Business Economics, 34(2), 105-125. https://doi.org/10.1007/s11187-009-9235-1

Brkic, I., Gradojevic, N., \& Ignjatijevic, S. (2020). The Impact of Economic Freedom on Economic Growth? New European Dynamic Panel Evidence. Journal of Risk and Financial Management, 13(2), 1-13. https://doi.org/10.3390/jrfm13020026

Bullock, H.E., Harlow, L.L., \& Mulaik, S.A. (1994). Causation Issues in Structural Equation Modeling Research. Structural Equation Modeling: A Multidisciplinary Journal, 1(3), 253-267. https://doi.org/10.1080/10705519409539977

Carmines, E.G., \& Zeller, R.A. (1979). Reliability and Validity Assessment. Sage University paper series on quantitative applications in the social sciences, No. 07-017. Beverly Hills, CA: Sage. https://doi.org/10.4135/9781412985642

Cassar, G. (2006). Entrepreneur Opportunity Costs and Intended Venture Growth. Journal of Business Venturing, 21, 610-632. https://doi.org/10.1016/j.jbusvent.2005.02.011

Castano-Martinez, M.S., Mendez-Picazo, M.T., \& Galindo-Martin, M.A. (2015). Policies to Promote Entrepreneurial Activity and Economic Performance. Management Decision, 53(9), 2073-2087. https://doi.org/10.1108/MD-06-2014-0393

Coase, R.H. (1937). The Nature of the Firm. Economica, 4, 386- 405. https://doi.org/10.1111/j.14680335.1937.tb00002.x

Coase, R.H. (1998). The New Institutional Economics. American Economic Review, 88(2), 72-74. Retrieved from https://www.jstor.org/stable/116895 on July 02, 2019.

Cortina, J.M. (1993). What Is Coefficient Alpha? An Examination of Theory and Applications. Journal of Applied Psychology, 78(1), 98-104. https://doi.org/10.1037/0021-9010.78.1.98

Danis, W.M., De Clercq, D., \& Petricevic, O. (2011). Are social networks more important for new business activity in emerging than developed economies? An empirical extension. International Business Review, 20(4), 394408. https://doi.org/10.1016/j.ibusrev.2010.08.005

De Clercq, D., Danis, W.M., \& Dakhli, M. (2010). The Moderating Effect of Institutional Context on the Relationship Between Associational Activity and New Business Activity in Emerging Economies. International Business Review, 19(1), 85-101. https://doi.org/10.1016/j.ibusrev.2009.09.002

Ferguson, P.P. (2004). Accounting for Taste: The Triumph of French Cuisine. Chicago: University of Chicago Press. https://doi.org/10.7208/chicago/9780226243276.001.0001

Fornell, C., \& Larcker, D.F. (1981). Structural Equation Models with Unobservable Variables and Measurement Error: Algebra and Statistics. Journal of Marketing Research, 18, 382-388. https://doi.org/10.2307/3150980

Fuentelsaz, L., Gonzalez, C., Maicas, J.P., \& Montero, J. (2015). How different formal institutions affect opportunity and necessity entrepreneurship. Business Research Quarterly, 18(4), 246-258. https://doi.org/10.1016/j.brq.2015.02.001

Fuentelsaz, L., Gonzalez, C., \& Maicas, J.P. (2018), Formal institutions and opportunity entrepreneurship: The contingent role of informal institutions. Business Research Quarterly, 22(1), 5-24. https://doi.org/10.1016/j.brq.2018.06.002

Jarvis, C.B., Mackenzie, S.B., \& Podsakoff, P.M. (2003). A Critical Review of Construct Indicators and Measurement Model Misspecification in Marketing and Consumer Research. Journal of Consumer Research, 30, 199218. https://doi.org/10.1086/376806

Gefen, D., Straub, D.W., \& Boudreau, M.C. (2000). Structural Equation Modeling and Regression: Guidelines for Research Practice. Communications of the Association for Information Systems, 4(7), 1-79. https://doi.org/10.17705/1CAIS.00407 
Greenwood, R., Suddaby, R., \& Hinings, C.R. (2002). Theorizing Change: The Role of Professional Associations in the Transformation of Institutionalized Fields. Academy of Management Journal, 45(1), 58-80. https://doi.org/10.2307/3069285

Hair, J.F., Black, W.C., Babin, B.J., \& Anderson, R.E. (2010). Multivariate Data Analysis, 7th ed. New Jersey: Prentice Hall.

Henseler, J., Ringle, C.M., \& Sinkovics, R.R. (2009). The Use of Partial Least Squares Path Modeling in International Marketing. Advances in International Marketing, 20, 277-319. https://doi.org/10.1108/S14747979(2009)0000020014

Herath, G. (2005). Analysis of the Potential and Problems of New Institutional Economics for Third World Development. International Journal of Social Economics, 32(10), 877-892. https://doi.org/10.1108/03068290510618515

Hwang, H., \& Powel, W.W. (2005). Institutions and Entrepreneurship. In S.A. Alvarez, R. Agarwal, \& O. Sorenson (Eds.), Handbook of Entrepreneurship Research (pp. 179-210). Kluwer Publishers. https://doi.org/10.1007/0387-23622-8_10

Kuchar, P. (2016). Entrepreneurship and institutional change: The case of surrogate motherhood. Journal of Evolutionary Economics, 26, 349-379. https://doi.org/10.1007/s00191-015-0433-5

Maguire, S., Hardy, C., \& Lawrence, T.B. (2004). Institutional Entrepreneurship in emerging fields: HIV/AIDS treatment advocacy in Canada. Academy of Management Journal, 47(5), 657-679. https://doi.org/10.2307/20159610

Menard, C., \& Shirley, M.M. (2011). New Institutional Economics: From Early Intuitions to a New Paradigm?. Ronald Coase Institute Working Paper, No. 8, Chevy Chase, MD: Ronald Coase Institute, 1-59. https://doi.org/10.1017/S174413741400006X

Moog, P. (2002). Human Capital and Its Influence on Entrepreneurial Success. Historical Social Research, 27(4), 157-180. Retrieved from http://www.jstor.org/stable/20757957 on July 12, 2020.

Muralidharan, E., \& Pathak, S. (2016). Informal institutions and international entrepreneurship. International Business Review, 26(2), 288-302. https://doi.org/10.1016/j.ibusrev.2016.07.006

Nissan, E., Galindo M.A., \& Picazo, M.T.M. (2012). Innovation, Progress, Entrepreneurship and Cultural Aspects. International Entrepreneurship and Management Journal, 8(4), 411-420. https://doi.org/10.1007/s11365012-0229-0

North, D.C. (1990). Institutions, institutional change and economic performance. New York: Cambridge University Press. https://doi.org/10.1017/СB09780511808678

North, D.C. (1992). Transaction Costs, Institutions, and Economic Performance. San Francisco, CA: ICS Press. https://doi.org/10.1111/j.1465-7295.1987.tb00750.x

Nunnally, J.C. (1967). Psychometric Theory, 1st ed. New York: McGraw-Hill.

Nunnally, J.C. (1978). Psychometric Theory, 2nd ed. New York: McGraw-Hill.

Nunnally, J.C., \& Bernstein, I.H. (1994). Psychometric Theory, 3rd ed. New York: McGraw-Hill.

Pelinescu, E. (2015). The impact of human capital on economic growth. Procedia Economics and Finance, 22, 184190. https://doi.org/10.1016/S2212-5671(15)00258-0

Petrescu, M. (2013). Marketing research using single-item indicators in structural equation models. Journal of Marketing Analytics, 1(2), 99-117. https://doi.org/10.1057/jma.2013.7

Reynold, P.D., Hay, M., \& Camp, S.M. (1999). Global entrepreneurship monitor: 1999 Executive Report, Kauffman Center for Entrepreneurial Leadership at the Ewing Marion Kauffman Foundation, Kansas City. MO. Retrieved from https://www.gemconsortium.org/ on August 26, 2019.

Romer, P.M. (1990). Endogenous Technological Change. Journal of Political Economy, 98(5), S71-S102. Retrieved from https://www.jstor.org/stable/2937632 on July 20, 2019.

Samadi, A.H. (2019). Institutions and entrepreneurship: unidirectional or bidirectional causality?. Journal of Global Entrepreneurship Research, 9(3), 1-16. https://doi.org/10.1186/s40497-018-0129-z

Sautet, F. (2005). The Role of Institutions in Entrepreneurship: Implications for Development Policy. Mercatus Policy Series: Policy Primer No. 1, February, Mercatus Center. Retrieved from https://ssrn.com/abstract=1264033 on June 21, 2019.

Schumpeter, J. (1934). Theory of Economic Development. New York: Oxford University Press.

Scott, W.R. (2008). Institutions and organizations, 3rd ed. Thousand Oaks, CA: Sage. 
Segars, A.H. (1997). Assessing the Unidimensionality of Measurement: A Paradigm and Illustration within the Context of Information Systems Research. Omega, International Journal of Management Science, 25(1), 107121. https://doi.org/10.1016/S0305-0483(96)00051-5

Shane, S., \& Venkataraman, S. (2000). The Promise of Entrepreneurship as a Field of Research. Academy of Management Review, 25(1), 217-226. https://doi.org/10.2307/259271

Sine, W.D., \& David, R.J. (2010). Institutions and Entrepreneurship. Research in the Sociology of Work, 21, 1-26. https://doi.org/10.1108/S0277-2833(2010)0000021005

Sine, W.D., David, R.J., \& Mitsuhashi, H. (2007). From Plan to Plant: Effects of Certification on Operational Startup in the Emergent Independent Power Sector. Organization Science, 18(4), 578-594. https://doi.org/10.1287/orsc.1070.0300

Stam, E., \& Van Stel, A. (2011). Types of entrepreneurship and economic growth. In M. Goedhuys, W. Naudé, \& E. Szirmai (Eds.), Innovation, entrepreneurship and economic development (pp. 78-95). Oxford: Oxford University Press. http://doi.org/10.1093/acprof:oso/9780199596515.003.0004

Stephan, U., \& Uhlaner, L.M. (2010). Performance-based vs socially supportive culture: a cross-national study of descriptive norms and entrepreneurship. Journal of International Business Studies, 41(8), 1347-1364. https://doi.org/10.1057/jibs.2010.14

Tenenhaus, M. (2008). Component-based Structural Equation Modelling. Total Quality Management \& Business Excellence, 19(7-8), 871-886. https://doi.org/10.1080/14783360802159543

Tolbert, P.S., David, R.J., \& Sine, W.D. (2011). Studying Choice and Change: The Intersection of Institutional Theory and Entrepreneurship Research. Organization Science, 22(5), 1332-1344. https://doi.org/10.1287/orsc.1100.0601

Urbano, D., \& Aparicio, S. (2016). Entrepreneurship Capital Types and Economic Growth: International Evidence. Technological Forecasting and Social Change, 102, 34-44. https://doi.org/10.1016/j.techfore.2015.02.018

Van Stel, A., Storey, D.J., \& Thurik, A.R. (2007). The effect of business regulations on nascent and young business entrepreneurship. Small Business Economics, 28(2), 171-186. https://doi.org/10.1007/s11187-006-9014-1

Williams, N., \& Vorley, T. (2015). Institutional asymmetry: How formal and informal institutions affect entrepreneurship in Bulgaria. International Small Business Journal, 33(8), 840-861. https://doi.org/10.1177/0266242614534280

Williamson, O.E. (1985). The Economics Institutions of Capitalism. New York, NY: Free Press.

Williamson, O.E. (2000). The New Institutional Economics: Take Stock, Looking Ahead. Journal of Economic Literature, 38(3), 595-613. http://doi.org/10.1257/jel.38.3.595 


\section{Authors}

The contribution of Khalilov Latif is $70 \%$ (shaped main concept and research idea, developed research model and methodology, analysed and interpreted the results) and the contribution of Yi Chae-Deug is $30 \%$ (helped with research ideas, methodology and analysis).

\section{Latif Khalilov}

PhD in Economics (2020, Pusan National University, Busan, Republic of Korea). His research interests include economic growth and development, human capital, and technology adoption.

Correspondence to: Latif Khalilov, PhD, Dalhousie University, Faculty of Science, Department of Economics, 6214 University Avenue, PO BOX 15000, Halifax, NS, B3H 4R2, Canada, e-mail: It290876@dal.ca; latif0983@gmail.com

ORCID $\odot$ http://orcid.org/0000-0002-8089-1522

\section{Chae-Deug Yi}

PhD in Economics (1993, The Ohio State University: Columbus, OH, US). He is Professor of Economics at the Department of International Trade, Pusan National University. His research interest includes international trade, international finance, and econometrics.

Correspondence to: Prof. Chae-Deug Yi, PhD, Pusan National University, College of Economics and International Trade, Department of International Trade, 2, Busandaehak-ro 63beon-gil, Geumjeong-gu, Busan, 46241, Republic of Korea, e-mail: givethanks@pusan.ac.kr

ORCID $\odot$ http://orcid.org/0000-0001-5866-5820

\section{Acknowledgements and Financial Disclosure}

The authors would like to thank the anonymous referees for their useful comments, which allowed to increase the value of this article. We were not provided with financial support for this study.

\section{Conflict of Interest}

The authors declare that the research was conducted in the absence of any commercial or financial relationships that could be construed as a potential conflict of interest.

\section{Copyright and License}

This article is published under the terms of the Creative Commons

Attribution - NoDerivs (CC BY-ND 4.0) License

http://creativecommons.org/licenses/by-nd/4.0/ 